\title{
Auditoria ambiental de conformidade como mecanismo para efetivação do princípio da prevenção e mitigação da responsabilidade administrativa ambiental
}

\section{Fernando Augusto Saleta Pacheco ${ }^{1,2}$}

\author{
${ }^{1}$ Universidade de São Paulo. Faculdade de Direito. Largo São Francisco, 95. Centro. \\ São Paulo-SP, Brasil (CEP 01005-010).E-mail: fsaletapacheco@gmail.com. \\ ${ }^{2}$ Université Jean Moulin Lyon. Faculté de Droit. 15 Quai Claude Bernard. 69007 \\ Lyon. França.
}

Resumo. Este artigo analisa a interação entre auditoria ambiental de conformidade, princípio da prevenção e responsabilidade administrativa em matéria ambiental. Com efeito, pretende-se examinar em que extensão a prévia promoção de uma auditoria ambiental de conformidade, enquanto medida de diligência de uma organização privada no que tange ao nível de cumprimento da legislação ambiental, serve para prevenir a ocorrência de infrações e danos ao meio ambiente, bem como para mitigar eventual penalidade administrativa, a partir da consideração dos antecedentes do infrator e do estudo comparativo à luz da experiência estadunidense sobre a matéria.

Palavras-chave: Auditoria ambiental de conformidade; Princípio da prevenção; Responsabilidade administrativa ambiental; Sanção administrativa; Mitigação.

Abstract. Environmental compliance audit as mechanism for effectiveness of prevention principle and mitigation of environmental administrative liability. This paper analyzes the interaction between environmental compliance audit, prevention principle and administrative liability in environmental matters. Indeed, it is intended to examine to what extent the prior promotion of an environmental compliance audit, as a measure of a private entity diligence in terms of compliance with the environmental legislation, serves to prevent the occurrence of environmental violations and damages, as well as to mitigate occasional administrative penalty, based on the offender's background and considering the United States of America experience related to the subject under discussion.

Keywords: Environmental compliance audit; Prevention principle; Environmental administrative liability; Administrative penalty; Mitigation.

Recebido

$11 / 04 / 2021$

Aceito

19/06/2021

Disponível on line

$27 / 06 / 2021$

Publicado

$31 / 08 / 2021$

Acesso aberto

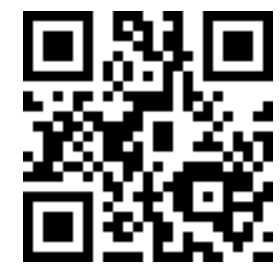

(D) 0000-0002-2451-612X Fernando Augusto Saleta Pacheco 
Résumé. Audit environnemental de conformité en tant que mécanisme de mise en ouvre du principe de prévention et atténuation de la responsabilité administrative en matière d'environnement. Cet article analyse l'interaction entre l'audit environnemental de conformité, le principe de prévention et la responsabilité administrative en matière d'environnement. En effet, il s'agit d'examiner dans quelle mesure la promotion préalable d'un audit environnemental de conformité, en tant que mécanisme de diligence d'une organisation privée à l'égard du niveau de respect de la législation environnementale, sert à prévenir la survenance d'infractions et des dommages à l'environnement, ainsi qu'à atténuer d'éventuelles sanctions administratives, à partir de la prise en compte des antécédents du contrevenant et de l'étude comparative à la lumière de l'expérience américaine sur ce sujet.

Mots-clés: Audit environnemental de conformité; Principe de prévention; Responsabilité administrative en matière d'environnement; Sanction administrative; Atténuation.

\section{Introdução}

0 tema a ser tratado neste artigo se insere nas linhas de pesquisa relacionadas ao Direito Ambiental, à gestão privada do meio ambiente e à responsabilidade ambiental, materializando-se a partir de uma perspectiva multidimensional, que abrange a correlação entre auditoria ambiental de conformidade, princípio da prevenção e responsabilidade administrativa em matéria ambiental.

Sob esses aspectos, busca-se analisar a importância e os efeitos jurídicos e ambientais decorrentes da realização de auditoria ambiental por entidades privadas, com foco na modalidade de conformidade, também conhecida por environmental compliance audit, cujo termo foi criado a partir da publicação realizada pela Agência de Proteção Ambiental dos Estados Unidos da América (Environmental Protection Agency - EPA), no ano de 1986, acerca da política de auditoria ambiental (Sales, 2001).

À luz do objetivo de impedir a ocorrência de danos e de agressões ao meio ambiente em virtude de atividades e empreendimentos potencial ou efetivamente poluidores, irrompe a ecoauditoria de conformidade como mecanismo de avaliação do status da efetivação dos requisitos ambientais da entidade auditada, cujos reflexos também podem servir a atenuar a imposição de eventuais sanções administrativas em razão dos antecedentes do infrator, tendo em vista o propósito relacionado ao cumprimento da legislação ambiental aplicável.

Por esse prisma, os institutos ora apreciados vinculam-se por uma vocação que lhes é comum: a proteção do meio ambiente.

É que a environmental compliance audit garante efetividade ao princípio da prevenção, pois, por meio do seu método investigativo, tenciona averiguar situações potencialmente desconformes à legislação e à regulamentação ambientais e, conforme o caso, retificá-las, a fim de que, enquanto ação preventiva, seja possível evitar o cometimento de infração ambiental, ou, se ocorrer, atenuar a respectiva penalidade aplicada, e, sobreutdo, a consumação de danos ao meio ambiente.

Nessa toada, em vista do escopo não só punitivo e intimidativo, mas, também, profilático e pedagógico inerentes à responsabilidade administrativa ambiental, mitigar a 
sanção administrativa imposta pela prática de uma infração ambiental em decorrência da realização da auditoria ambiental de conformidade, significa reconhecer, a depender da análise do caso concreto, o impulso espontâneo da organização privada para impedir a conduta infracional e, ainda que de modo indireto, incentivar os demais agentes do corpo social a adequarem-se aos parâmetros legais e regulamentares fixados, por meio de métodos de autopoliciamento.

Assim, a partir da interação dessa tríade, estimula-se que as entidades do setor privado estabeleçam mecanismos de autorregulação para que as situações avessas ao ordenamento jurídico se tornem, mediante a promoção de uma ecoauditoria de conformidade, cógnitas e possam ser corrigidas previamente à ocorrência de infração administrativa ambiental, facultando-se a concessão do benefício da atenuação da correspondente penalidade administrativa àquele que, apesar da condução da referida diligência, tenha cometido ato infracional, se o caso.

\section{Material e métodos}

Para o desenvolvimento deste trabalho, empregar-se-á o método de abordagem lógico-dedutivo, segundo o qual será possível extrair conclusões particulares a partir do estudo e da análise de premissas gerais relativas às questões e aos aspectos apresentados anteriormente.

Nesse sentido, a elaboração deste estudo parte da apreciação de instrumentos jurídicos técnicos, tais como o exame da legislação aplicável, da doutrina especializada e, inclusive, de decisões judiciais que guardem relação de pertinência com as auditorias ambientais de conformidade, o princípio da prevenção e a responsabilidade administrativa ambiental.

Convém salientar que, para a elucidação das raízes históricas e para a fixação de determinados conceitos, especialmente quanto às auditorias ambientais, recorrer-se-á à análise de material alienígena, em particular do pensamento jurídico estadunidense, por considerar que os Estados Unidos dispõem de um sistema de proteção ambiental evoluído, se comparado ao nacional, no que tange ao tema desta pesquisa.

Dessa forma, a análise da legislação terá como objetivo delimitar formalmente o assunto, ao passo que o estudo da literatura jurídica se prestará ao delineamento dos posicionamentos doutrinários já existentes, complementando-se o desenvolvimento desta pesquisa acadêmica com decisões jurisprudenciais relevantes para o entendimento do tema ora especificado.

\section{Resultados e discussão}

\section{Auditoria ambiental de conformidade}

A literatura especializada aponta que a origem remota da auditoria ambiental de conformidade surgiu da prática voluntária de algumas empresas estadunidenses, no início da década de 1970 (Sales, 2001), a fim de que suas atividades se adequassem ao crescente número de leis ambientais que haviam sido promulgadas na década precedente, bem como do papel desempenhado pela Securities and Exchange Commission (SEC), agência federal norte-americana responsável pela supervisão e regulação do mercado de valores mobiliários em âmbito nacional, e da publicação do relatório Assessment for Innovative Enforcement Procedures (ACUREX Report), pela EPA, em 1979 (Campos e Lerípio, 2009).

Posteriormente, a agência estadunidense de proteção do meio ambiente definiu a auditoria ambiental como "uma revisão sistemática, documentada, periódica e objetiva por parte das entidades reguladas sobre as práticas e operações de suas instalações relativas ao cumprimento de requisitos ambientais", conforme publicação no Diário Oficial do 
Governo Federal dos Estados Unidos da América (Federal Register), de 9 de julho de 1986 (USEPA, 1986).

Nessa esteira, a partir do Comprehensive Environmental Response, Compensation, and Liability Act (CERCLA), ato promulgado pelo Congresso Estadunidense em 11 de dezembro de 1980, que autorizou autoridades federais a tributar indústrias químicas e petrolíferas responsáveis por lançamentos ou ameaças de liberação de substâncias nocivas à saúde pública ou ao meio ambiente (Witkin, 2003), há de se destacar a maximização da aplicabilidade do instituto ora tratado, tendo em vista a exigência de avaliação ambiental prévia como um dos procedimentos capazes de elidir a respectiva responsabilidade (Sales, 2001).

Como reflexo de tal cenário, a EPA tem divulgado, desde 1997, diversos protocolos acerca da condução de auditorias ambientais de conformidade sob aspectos específicos, a fim de fornecer às entidades reguladas orientações singulares para permitir que avaliem periodicamente o grau de conformidade aos requisitos ambientais previstos na legislação federal.

Em âmbito nacional, o desenvolvimento da auditoria ambiental iniciou-se no fim da década de 1980, como fruto de programas voluntários desempenhados por corporações estrangeiras que mantinham atividades no Brasil. A partir desse momento, algumas companhias brasileiras também vêm gradualmente implementando iniciativas com o fito de propiciar o amoldamento da gestão ambiental às exigências mercadológicas e consumeristas atuais, sobretudo indústrias de grande porte, cujo potencial lesivo ao meio ambiente é considerado alto.

Por outro lado, em determinados casos, a execução das auditorias ambientais tornou-se obrigatória em decorrência de imposição legislativa, em especial no que tange aos setores industriais, por parte de alguns estados-membros. Nessa esteira, apontam-se as unidades federativas do Rio de Janeiro (Lei no 1.898/1991) (Rio de Janeiro, 1991), Minas Gerais (Lei no 10.627/1992) (Minas Gerais, 1992), Espírito Santo (Lei no 4.802/1993) (Espírito Santo, 1993), São Paulo (Lei no 9.509/1997) (São Paulo, 1997) e Rio Grande do Sul (Lei no 11.520/2000) (Rio Grande do Sul, 2000) como protagonistas desse movimento regulatório.

Com efeito, esta variante específica de auditoria ambiental, conduzida de forma voluntária e apreciada sob o prisma interno das empresas, consiste na análise da conformidade das atividades desempenhadas por entidades reguladas aos requisitos legais, às normas técnicas e às políticas de natureza ambiental, cuja finalidade se fundamenta na avaliação do status e do nível de adequação da entidade auditada à legislação ambiental aplicável.

Quanto à importância da diligência sob análise, impõe-se considerar que a gestão do meio ambiente não compete exclusivamente a um agente, seja público, seja privado. Por força do direito fundamental relativo ao meio ambiente ecologicamente equilibrado e da previsão constitucional inscritos no caput, do art. 225 (Brasil, 1988), surge o dever, e não mais mera faculdade, que vincula não só o Poder Público à tutela do meio ambiente, mediante sua defesa e preservação, mas, também, a coletividade, que, da mesma forma, é titular desta obrigação de fazer, positiva e geral (Milaré, 2015).

Conclui-se, assim, que a ação dos diferentes agentes se complementa, na medida em que cada qual detém uma abordagem própria sobre os métodos a serem empregados para a concretização do dever constitucional, contribuindo-se para alcançar um objetivo comum, cujo chamamento é universal.

Nesse quadro, no que tange à gestão privada do meio ambiente, o programa corporativo de auditoria ambiental revela-se elementar para a efetivação do desempenho da função ativa imposta aos cidadãos, no sentido de defender e preservar o mundo natural, circunstância que decorre, notadamente, de duas ponderações. 
Prima facie, deriva do fato de que a natureza das atividades desenvolvidas pelas empresas, no geral e em comparação aos indivíduos isoladamente considerados, apresenta maior complexidade operacional e gera maiores impactos ambientais. Tal tendência é observada, sobretudo, desde o advento da Revolução Industrial, um dos eventos responsáveis pela alteração dos modos de produção tradicionais, ocorrida na Inglaterra, no século XVIII, tendo em vista que "a poluição é sem dúvida umas das extremidades mais marcantes do modo de produção e consumo da sociedade moderna, que tem a indústria como uma de suas características marcantes" (Juras, 2015).

De outro turno, deve-se pontuar, que, no caso pátrio, a maior parte das entidades privadas não atendem ao chamado constitucional, especialmente, em razão da pressão relacionada ao necessário crescimento econômico em curto prazo, do exacerbado consumismo e da falta de investimentos ambientais (Milaré, 2015).

Portanto, ante a frágil mentalidade ambiental-corporativa, cujo foco centra-se nas questões econômicas, à míngua da sustentabilidade ambiental, surge a auditoria ambiental como mecanismo para, dentre outras finalidades, efetivar o princípio da prevenção, desenvolver uma política empresarial para o meio ambiente, buscar a conformidade legal do sistema produtivo, analisar as práticas gerenciais e estimar os riscos e as responsabilidades das atividades desempenhadas e dos agentes executores (Campos e Lerípio, 2009).

Em termos gerais, ao alcançar os objetivos a que se presta, a auditoria ambiental propicia diversas repercussões positivas, seja para a própria empresa auditada, seja para 0 meio ambiente, seja, ainda, para a sociedade civil.

Como consequências de sua prática, sobrevêm, dentre outros benefícios, a análise e a mitigação dos passivos ambientais; o controle dos aspectos ambientais referentes às práticas e aos procedimentos das unidades operacionais da organização; a identificação do nível de conformidade das atividades auditadas às exigências legais; o estabelecimento e a implementação de políticas ambientais necessárias à consecução dos objetivos empresariais; e a possível atenuação de penalidades em ações administrativas na seara do poder de polícia ambiental, materializado por atividades de controle e de sanção (Sales, 2001).

Dessa forma, resta demonstrada a importância basilar dos programas de auditoria ambiental, compostos, em regra, pelas fases de planejamento, de execução e de confecção do respectivo relatório, no que concerne à lógica de gerenciamento ambiental por parte das entidades privadas, enquanto ferramenta capaz de amparar o dever constitucional de preservação e de defesa do meio ambiente, bem como de contribuir para um sistema de gestão privada mais sustentável.

A etapa inicial, mais abrangente do que as outras e que contempla a fixação do objetivo, do escopo, dos critérios a serem utilizados, dos recursos necessários e da equipe de auditores, é essencial para ajustar a amplitude e o conteúdo da diligência almejada, assim como para assegurar a sua efetividade (Campos e Lerípio, 2009).

No que tange ao objetivo, há de se definir especificamente qual modalidade de auditoria ambiental será realizada, in casu, a de conformidade, de modo a evitar o desarranjo programático entre as partes envolvidas e a permitir a coerência do resultado final (La Rovere et al., 2001).

O escopo, por sua vez, envolve o estabelecimento dos limites e das extensões da auditoria ambiental em termos de localização geográfica, limites organizacionais relacionados à unidade funcional da organização submetida à diligência, objeto de auditagem, período e tema ambiental, com a definição de quais itens serão avaliados durante os trabalhos, tais como a poluição atmosférica, a contaminação da água, a gestão de resíduos sólidos, o uso de recursos naturais e os riscos ambientais (Campos e Lerípio, 2009). 
Adiante, faz-se necessário, à luz do objetivo e do escopo anteriormente fixados, estabelecer os critérios da auditoria ambiental, que correspondem às políticas, às práticas, aos procedimentos e aos regulamentos, de natureza legal, organizacional ou normativa (La Rovere et al., 2001), que serão levados a efeito pelo auditor com o fito de proceder à coleta das indicações e das evidências aptas a patrocinar a auditoria.

Em seguida, elegem-se os instrumentos necessários a subsidiar a confecção do programa de auditoria ambiental, isto é, o fornecimento de recursos humanos, físicos, financeiros, logísticos e tecnológicos suficientes para que seja possível a sua elaboração, nos termos dos fatores previamente elencados.

Por fim, delimitados os elementos acima, seleciona-se a equipe de auditores encarregada pela condução dos trabalhos. Faz-se necessário, neste momento, que o quadro de profissionais selecionados goze de imparcialidade e de independência no que tange à unidade a ser auditada (Campos e Lerípio, 2009), de modo que não haja relação de subordinação entre os agentes e a respectiva fração organizacional objeto da auditoria.

Concluído o planejamento da ecoauditoria de conformidade, irrompe a fase de preparação, na qual se promove a análise preliminar de documentos, a elaboração do plano de auditoria, a confecção e a adaptação dos instrumentos necessários à execução da diligência, além do estudo da legislação e das normas aplicáveis às atividades da unidade auditada.

Em certa medida, os empreendimentos e atividades potencialmente poluidores e utilizadores de recursos ambientais sujeitam-se à regulamentação jurídica, em nível federal, estadual e municipal. Ademais, em razão da amplitude da legislação ambiental brasileira, requer-se profundas pesquisas, conhecimentos e análises, impondo-se que tal estudo, conduzido pela equipe de auditores, seja realizado minuciosamente (La Rovere et al., 2001), a garantir que se contemplem todas as possíveis normas vigentes e que se aplicam à ecoauditoria.

Em continuidade à fase preparatória, segue-se a etapa da execução da auditoria ambiental in loco, composta por uma cadeia de atos materializada pela apresentação, pela compreensão da unidade auditada e de sua gestão, pela coleta de evidências, pela avaliação das evidências identificadas e pela exposição dos resultados (Campos e Lerípio, 2009).

Finalizada a fase executiva, elabora-se o relatório, que consiste no registro formal dos resultados da ecoauditoria, consubstanciado pelo documento em que a equipe de auditores apresenta as evidências de conformidade e de não-conformidade da empresa em comparação com os critérios da auditoria (La Rovere et al., 2001), constituindo-se, portanto, em instrumento de trabalho para os gestores das empresas e subsídio para que a entidade tenha ciência do nível de adequação das suas atividades ao ordenamento jurídico no que tange às questões ambientais.

\section{Princípio da prevenção}

Decerto, o termo "princípio" é, para os fins deste estudo, utilizado no sentido de fundamento e de alicerce do ordenamento jurídico (Ferreira Filho, 2012). Trata-se, com efeito, de "normas jurídicas impositivas de uma optimização, compatíveis com vários graus de concretização, consoante os condicionamentos fáticos e jurídicos" (Canotilho, 2003). Ademais, servem os princípios tanto como limite à atuação do jurista quanto como vetor interpretativo e fonte subsidiária das normas jurídicas (Barroso, 1998).

Quer-se dizer que os princípios, no desempenho de suas funções, representam o mandamento central de um sistema, sobre o qual este se alicerça, "compondo-lhes o espírito e servindo de critério para sua exata compreensão e inteligência, exatamente por definir a lógica e a racionalidade do sistema normativo, no que lhe confere a tônica e lhe dá sentido harmônico" (Mello, 2014). 
Por sua vez, o princípio da prevenção consiste no dever jurídico de evitar antecipadamente a consumação de danos ao meio ambiente mediante a adoção de medidas ambientais acauteladoras, com base em informação prévia e cientificamente conhecida quanto à repercussão das atividades humanas sobre o meio ambiente (Machado, 2015).

Nessa toada, faz-se imprescindível diferenciar o princípio da prevenção, no contexto do Direito Ambiental, do princípio da precaução. Aquele se refere ao tratamento de riscos ou impactos cujo conhecimento já é consolidado e patente pela ciência, ao passo que este visa ao gerenciamento de riscos ou impactos ainda desconhecidos. Assim, enquanto a prevenção pressupõe o perigo concreto e certo, a precaução lida com o perigo abstrato e incerto (Milaré, 2015).

Apesar da distinção ajustada acima, o princípio da prevenção compreende o momento anterior ao instante da consumação do dano ambiental, a fim de, como ação preventiva, e não reparadora, quando a agressão já ocorreu, evitá-lo.

Isso porque o retorno ao status quo é praticamente impossível, ante a irreparabilidade, em regra, da degradação ambiental (Lemos, 2008), ou, quando possível reparar, em algum grau, o dano consumado ao meio ambiente, os seus efeitos são insatisfatórios, tendo em vista a dificuldade do restabelecimento das características essenciais do bem afetado, sendo, na maior parte dos casos, a prevenção uma das únicas soluções para elidi-lo.

Destina-se, pois, o princípio da prevenção ao impedimento da ocorrência de danos ambientais, mediante a estipulação e o cumprimento de providências preventivas, as quais devem ser observadas anteriormente à implantação e à operação de atividades e de empreendimentos considerados efetiva ou potencialmente poluidores.

Em poucas palavras, resume-se o cerne do princípio da prevenção: é preciso agir antecipadamente para "que se forme o conhecimento do que prevenir" (Machado, 2015). Nesse particular, constata-se a contemporaneidade do assunto ora analisado, tendo em vista a ocorrência de diversos desastres ambientais em território nacional, com destaque para o rompimento das barragens de rejeitos operadas pelas empresas mineradoras Samarco e Vale, nos Municípios de Mariana e Brumadinho, Estado de Minas Gerais, em novembro de 2015 e janeiro de 2019, respectivamente, além do vazamento de óleo decorrente das atividades da empresa Chevron, na Bacia de Campos, Estado do Rio de Janeiro, no final de 2011, os quais poderiam ter sido minimizados ou até mesmo evitados caso se dispusesse de uma efetiva política de compliance ambiental (Trennepohl, 2020).

Na Constituição Federal de 1988, o princípio da prevenção está previsto, de forma implícita (Lemos, 2008), ao se impor ao Poder Público e à coletividade o dever de defender e de preservar o meio ambiente para as presentes e as futuras gerações e, expressamente, ao se dispor sobre modos preventivos de atuação, que competem ao Estado, para garantir o cumprimento e o exercício do direito ao meio ambiente ecologicamente equilibrado, nos termos do art. 225, caput e $\S 1$ o, da Carta Maior (Brasil, 1988).

Outrossim, o caráter prevencionista também figura no plano infraconstitucional, notadamente por meio de institutos jurídicos de controle como o licenciamento ambiental, o estudo de impacto ambiental e o respectivo relatório de impacto ambiental (EIA/RIMA), as audiências públicas e as sanções administrativas.

De igual modo, a auditoria ambiental de conformidade está intrinsecamente relacionada ao princípio da prevenção, porquanto seus objetivos, no âmbito da profilaxia ambiental, servem a concretizá-lo. Ela busca justamente trazer à luz as disfunções relacionadas às atividades desenvolvidas pelas empresas a fim de que, nos exatos termos do que enuncia o referido princípio, seja possível administrar tais riscos ambientais e mitigá-los, com a finalidade derradeira de, preventivamente, evitar que o dano em si ocorra. 
Como já pontuado, enquanto ferramenta apta a concretizar o princípio sub examine e, a depender da análise do caso concreto, a environmental compliance audit pode, ainda, servir a atenuar a responsabilidade administrativa ambiental.

\section{Responsabilidade administrativa em matéria ambiental}

Na seara ambiental, a responsabilização em face de condutas lesivas ao meio ambiente desdobra-se em três esferas autônomas: civil, penal e administrativa, as quais

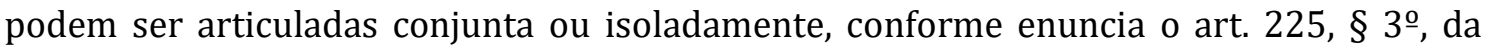
Carta Magna (Brasil, 1988).

Neste artigo, entretanto, o tema está adstrito à responsabilidade ambiental administrativa, cujo regramento legal é disciplinado pela Lei no 9.605/1998 (Brasil, 1998) e pelo Decreto no 6.514/2008 (Brasil, 2008).

Com efeito, essa modalidade de responsabilidade expressa a "intervenção sancionadora mediante a aplicação da penalidade administrativa, a partir da caracterização legal de uma infração" (Dino Neto et al., 2011). 0 ato infracional, a seu passo, é legalmente conceituado como toda ação ou omissão que viole as regras jurídicas de uso, gozo, promoção, proteção e recuperação do meio ambiente, a teor do disposto no art. 70, caput, da Lei no 9.605/1998 (Brasil, 1998).

Do cometimento de uma infração administrativa ambiental, após o devido processo legal, pode resultar a aplicação de sanções administrativas, consideradas "um mal infligido pela Administração a um administrado como consequência de uma conduta ilegal" (Enterría e Fernández, 1991). Dentre elas, incluem-se a advertência, as multas simples e diária, além da restrição de direitos, conforme previsto nos arts. 72 , da Lei $\mathrm{n}^{\mathrm{o}}$ 9.605/1998 (Brasil, 1998), e art. 3ํ, do Decreto no 6.514/2008 (Brasil, 2008).

Importa frisar que, nesse sentido, o exercício do poder sancionador estatal denota lídimo caráter geral profilático e pedagógico, a fim de inibir e de desestimular condutas que lesem o meio ambiente, evitando a consumação do dano ambiental, em estreita e pertinente relação com o princípio da prevenção, que estende seus efeitos para além do infrator, atingindo-se, igualmente, os demais membros da coletividade (Santos et al., 1997).

Ao rigor desse raciocínio, sublinham-se os reflexos, cada vez mais patentes do princípio da prevenção sobre a infração administrativa, visto que, dispensada a produção de evento danoso para sua caracterização, tenciona-se, mediante a adoção de tipos de perigo, antecipar-se à lesão sobre o bem tutelado (Dino Neto et al., 2011).

Avulta-se, nesse quadro e para desempenhar as atribuições legalmente conferidas pelo legislador, o poder de polícia ambiental que, alicerçado na definição consagrada pelo art. 78, do Código Tributário Nacional (Brasil, 1966), pode ser definido da seguinte forma:

Poder de polícia ambiental é atividade da Administração Pública que limita ou disciplina direito, interesse ou liberdade, regula a prática de ato ou a abstenção de fato em razão de interesse público concernente à saúde da população, à conservação dos ecossistemas, à disciplina da produção e do mercado, ao exercício de atividades econômicas ou de outras atividades dependentes de concessão, autorização/permissão ou licença do Poder Público de cujas atividades possam decorrer poluição ou agressão à natureza (Machado, 2015).

É mediante o exercício desse poder de polícia que o Poder Público, pelas autoridades a quem o ordenamento jurídico atribui competência, aplica ordens e proibições (Meirelles, 2012) e salvaguarda os direitos fundamentais (Schirato et al., 2017), in casu, a garantia ao meio ambiente ecologicamente equilibrado, principalmente por meio das normas limitadoras e sancionadoras na esfera ambiental, no desempenho da tutela administrativa do meio ambiente. 
Sobre a controversa natureza jurídica da responsabilidade administrativa na seara ambiental, as discussões articuladas no âmbito da literatura especializada e da jurisprudência são controversas. A questão, nesse particular, cinge-se à imprescindibilidade, ou não, da configuração de culpa ou de dolo na prática de infração administrativa ambiental para que se apliquem as respectivas sanções ao infrator.

Delineiam-se três correntes doutrinárias acerca do tema.

Num primeiro plano, surge o entendimento, sustentado por Dino Neto et al. (2011), Machado (2015) e Freitas (2005), pelo qual, independentemente do elemento subjetivo do agente, materializado por dolo ou culpa, e mediante a mera violação da norma de conduta descrita, aperfeiçoa-se o ilícito administrativo ambiental, a caracterizar a responsabilidade objetiva. Esta premissa, todavia, comporta exceções, ao permitir que, nas hipóteses expressamente fixadas pelo ordenamento jurídico, previstas sobretudo nos

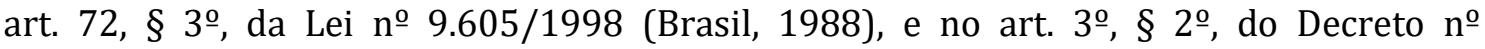
6.514/2008 (Brasil, 2008), exija-se a comprovação da culpa.

É que, segundo tal tese, a função regulatória do Direito Administrativo não se presta a impor um castigo pelo dano aventado ao bem jurídico que se tutela, mas pretende desestimular as práticas atentatórias à ordem administrativa e, com isso, propiciar a manutenção do bem estar coletivo (Dino Neto et al., 2011).

Um detalhe importante há de ser mencionado: a partir dos preceitos aduzidos por parcela da doutrina ambientalista e da jurisprudência, pretende-se, na verdade, transferir à responsabilidade administrativa o caráter objetivista da responsabilidade civil, cujos pressupostos se fundam na ação ou omissão, na relação de causalidade e no dano, sem que se fale em comprovação da culpa (Lemos, 2008), nos termos da Política Nacional do Meio Ambiente, com previsão legal nos artigos 4을, inciso VII, e 14, § $1^{\circ}$, ambos da Lei $\mathrm{n}^{\mathrm{o}}$ 6.938/1981 (Brasil, 1981), a, no mínimo, ser questionado, pois cada sistema de responsabilidade ambiental responde a uma lógica que lhe é própria.

Em seu turno, desponta a corrente doutrinária subjetivista, patrocinada por Osório (2011), Oliveira (2012) e Vitta, 2003), segundo a qual o dolo ou a culpa do agente é imprescindível à caracterização da infração administrativa ambiental, evidenciando-se a subjetivação e a culpabilidade como elementos necessários ao deslinde da questão, forte nos direitos e nas garantias fundamentais materializadas pela individualização da pena, pelo contraditório e a ampla defesa no processo administrativo e pelo princípio da não culpabilidade, que constam do art. 50, incisos XLVI, LV e LVII, respectivamente, da Constituição Federal de 1988 (Brasil, 1988).

Nesse sentido, as sanções administrativas, assim como as penas, constituem espécies do jus puniendi estatal, motivo pelo qual se aplicam, com temperamentos, os princípios penais ao direito administrativo sancionatório (Osório, 2011). É dizer, a "tipicidade, antijuridicade e culpabilidade devem fazer parte da infração administrativa" (Bim, 2010), mesmo que em graus de rigidez distintos da seara penal.

Há de se acentuar, ainda, a posição intermediária proposta por Milaré (2015), informada pela teoria da culpa presumida, em que há a presunção relativa quanto à responsabilidade do suposto infrator, circunstância esta capaz de ensejar, desde já, a aplicação da sanção abstratamente prevista, permitindo-lhe, contudo, mediante a inversão do ônus probatório, que se prove o contrário. No entanto, caso o agente não se desincumba deste ônus, a presunção, antes relativa, dará lugar à certeza.

Explica-se, para a administração, basta a presença de indícios da violação do dever de cuidado, cabendo ao infrator comprovar a falta do elemento subjetivo ou invalidar o juízo indiciário da infração, tendo em vista que, por essa articulação, busca-se tutelar um interesse maior, consubstanciado num bem, integrante do patrimônio público e de usufruto da coletividade presente e futura, o meio ambiente.

Neste artigo, adotar-se-á a teoria subjetiva da responsabilidade administrativa em matéria ambiental, a exigir a demonstração de culpa ou de dolo na conduta do infrator. É 
que, assim como na esfera criminal, indispensável se revela a verificação da culpabilidade do agente no plano do direito administrativo (Bim, 2010), inclusive porque, se fosse ela prescindível, não seria viável estimar eventual grau de atenuação da responsabilidade do infrator a partir da análise do aspecto subjetivo ínsito à sua psique.

A culpabilidade, enquanto princípio que norteia o direito sancionador, serve a limitar o jus puniendi administrativo e a assegurar que sejam respeitados o Estado Democrático de Direito e os direitos e as garantias fundamentais elencados na Carta Magna (Nobre Júnior, 2000), se diferente fosse, far-se-ia dela letra morta.

No mais, existe uma tendência jurisprudencial mais recente, desde 2012 e em especial do Superior Tribunal de Justiça (STJ), cuja acepção indica que, para caracterizar a infração administrativa ambiental, recai a necessidade de constatação do elemento subjetivista e do nexo de causalidade entre a conduta e o evento danoso. Nesse sentido, destacam-se os seguintes julgados: EREsp 1.318.051/RJ, relator Ministro Mauro Campbell Marques, julgado em 08 de maio de 2019; RESp 1.640.243/SC, relator Ministro Herman Benjamin, julgado em 07 de março de 2017; RESp 1.401.500/PR, relator Ministro Herman Benjamin, julgado em 16 de agosto de 2016; AgRg no AREsp 62.584/RJ, relator Ministro Sérgio Kukina, julgado em 07 de outubro de 2015; e RESp 1.251.697/PR, relator Ministro Mauro Campbell Marques, julgado em 17 de abril de 2012.

Fixadas tais premissas, os pressupostos ensejadores da responsabilidade administrativa subjetiva ambiental, a partir da configuração de uma infração ao meio ambiente, exigem, em síntese, a apuração de dois requisitos, quais sejam, a conduta culposa e a sua ilicitude (Milaré, 2015).

O comportamento culposo, causado por imprudência, negligência ou imperícia, que decorre de ato comissivo ou omissivo violador das regras jurídicas de uso, gozo, promoção, proteção e recuperação do meio ambiente, pode ser imputado tanto a pessoas físicas quanto a pessoas jurídicas responsáveis pelo cometimento da infração, nos termos dos arts. 3o e 70, caput, ambos da Lei no 9.605/1998 (Brasil, 1998).

A ilicitude, caracterizada pelo comportamento contrário àquele estabelecido pela norma jurídica em razão da desobediência às normas constitucionais, legais ou regulamentares, que é pressuposto da sanção, representa elemento essencial para a configuração da infração administrativa ambiental.

Por fim, convém salientar que o dano ambiental, em si, não enseja a responsabilização administrativa, pois, para tanto, é preciso que ele seja "enquadrável como o resultado descrito em um tipo infracional ou provocado por um comportamento omissivo ou comissivo violador de regras jurídicas" (Milaré, 2015).

Perspectiva estadunidense sobre a mitigação da responsabilidade ambiental decorrente da realização de auditoria ambiental de conformidade

A política de auditorias ambientais, desenvolvida nos Estados Unidos, pela EPA, no âmbito do programa Environmental Auditing Policy Statement. Federal Register, em 1986, a fim de incentivar a realização de auditoria ambiental por entidades regulamentadas para que alcancem e mantenham a conformidade de suas atividades e operações com as leis e os regulamentos ambientais, bem como de identificar e corrigir eventuais riscos e danos ambientais detectados, representa o núcleo embrionário da mitigação da responsabilidade em matéria ambiental decorrente da elaboração da ecoauditoria de conformidade.

Decerto, a referida agência ambiental, representada por seus agentes e nos termos da regulação administrativa, no momento da autuação da infração ambiental e no exercício do seu poder discricionário, pode considerar os esforços genuínos das entidades regulamentadas para evitar e retificar as violações e problemáticas ambientais, mediante a adoção de medidas preventivas, a fim de afastar as não-conformidades, por meio das environmental compliance audits. 
Em igual sentido e no ano de 1995, a EPA emitiu sua política final, denominada Voluntary Environmental Self-Policing and Self-Disclosure Interim Policy Statement (USEPA, 1995), relacionada aos incentivos para a autorregulação, cujo propósito se fundou na maximização da proteção da saúde humana e do meio ambiente, incentivando as organizações privadas a descobrir, divulgar, corrigir e prevenir voluntariamente as respectivas violações à legislação ambiental, mediante a concessão de benefícios, que incluem reduções no valor de penalidades civis e recomendações para que tais entidades não sejam processadas criminalmente.

Após efetuar a revisão do documento ora mencionado, uma nova versão dessa política foi disponibilizada, nos anos 2000, pelo órgão ambiental americano, sendo designada por Incentives for Self-Policing: Discovery, Disclosure, Correction and Prevention of Violations (USEPA, 2000). De acordo com esta publicação mais recente, os incentivos oferecidos às entidades supramencionadas são diferentes, a depender da contemplação de nove condições estabelecidas pela EPA, quais sejam: (i) descoberta sistemática da violação por meio de uma auditoria ambiental ou da implementação de um sistema de gerenciamento de conformidade; (ii) descoberta voluntária da violação, e não decorrente de um procedimento legalmente exigido de monitoramento, de amostragem ou de auditoria; (iii) divulgação imediata da violação, por escrito, à EPA, no prazo de 21 dias após a descoberta - que ocorre quando qualquer executivo, diretor, funcionário ou agente da entidade dispõe de uma base objetivamente razoável para acreditar que uma violação ocorreu ou possa ter ocorrido - ou num período menor, se assim a lei o exigir; (iv) descoberta e divulgação independentes perante a EPA ou outro agente regulador, antes que a violação seja identificada por estes mediante investigação própria ou com base em informações fornecidas por terceiros; (v) correção e remediação da violação em 60 dias corridos, na maioria dos casos, a partir da data da respectiva descoberta; (vi) impedir a recorrência da violação depois que tenha ela sido divulgada; (vii) não se tratar de reincidência, isto é, de violações específicas ou intimamente relacionadas que tenham ocorrido na mesma instalação nos últimos 3 anos ou aquelas que tenham se produzido como parte de um padrão em múltiplas unidades pertencentes ou operadas pela mesma entidade nos últimos 5 anos; (viii) não se tratar de caso de violações inadmitidas, tais como aquelas que tenham resultado em sérios e atuais danos ambientais, possam ter representado uma ameaça iminente e substancial ao meio ambiente ou descumpram termos específicos de uma ordem administrativa ou judicial ou de um acordo; e (ix) a cooperação da entidade sub examine com as autoridades, sobretudo dos órgãos ambientais.

Nessa toada, existem duas modalidades de incentivos na seara civil: (i) a mitigação de $100 \%$ de qualquer penalidade baseada na gravidade, medida pela porção da penalidade que ultrapassa a parte correspondente ao ganho econômico da organização em virtude das desconformidades da sua conduta, quando forem cumpridas todas as condicionantes; e (ii) a atenuação de $75 \%$ de qualquer penalidade baseada na gravidade, se a primeira condição não for preenchida.

Sob o aspecto criminal, em regra, a vantagem concedida se consubstancia pelo pronunciamento desfavorável da EPA à instauração de processo criminal pelas autoridades competentes, sobretudo o Departamento de Justiça, desde que a organização privada reúna todas as condicionantes, independentemente de atender ao requisito da descoberta sistemática de violações, e que a sua política de autorregulação, descoberta e divulgação tenha sido conduzida de boa-fé, provando-se uma estrutura apta a prevenir a reincidência de transgressões à legislação penal ambiental.

Contudo, também há outras exceções no âmbito dos crimes ambientais: não são elegíveis para os benefícios relatados as entidades que repetirem violações, resultantes em danos reais ao meio ambiente ou que possam apresentar uma ameaça iminente e 
substancial, bem como as organizações privadas cujas violações ambientais decorram da consciente desconsideração de suas obrigações legais.

Não se pode olvidar que a EPA se reserva o direito de coletar qualquer benefício econômico que possa ter sido obtido como resultado do descumprimento da legislação ambiental, ainda que a entidade tenha cumprido todas as condições da política.

Com essa medida, intenta-se compelir a entidade regulada a cumprir tempestivamente suas obrigações legais e promover o princípio da livre concorrência, ao não permitir que aqueles que violam a lei sejam beneficiados pela obtenção ilícita de vantagens econômicas, a prejudicar seus concorrentes no mercado.

\section{Viabilidade no direito ambiental brasileiro}

De plano, imperioso sublinhar que, diferentemente da realidade estadunidense, no direito pátrio inexiste previsão legal ou infra legal específica acerca da possível mitigação das penalidades administrativas impostas ou a serem impostas aos infratores em virtude da realização de auditorias ambientais de conformidade.

Não obstante a constatação desse fato, a atual legislação brasileira que dispõe sobre as sanções administrativas derivadas de condutas e atividades lesivas ao meio ambiente permite, ainda que sob termos genéricos e mediante esforço hermenêutico (Milaré, 2015), que haja a atenuação das correspondentes penalidades em razão, dentre outras circunstâncias, dos antecedentes do infrator, no que tange à conformidade em face da legislação ambiental, a teor do disposto no art. 6o , inciso II, da Lei no 9.605/1998 (Brasil, 1998), e no art. 4ํㅜ , inciso II, do Decreto no 6.514/2008 (Brasil, 2008).

Importa, nesse quadro, que o conceito de antecedentes seja considerado em relação ao cumprimento das normas ambientais, ou seja, deve-se ter em vista a conduta pretérita do infrator em relação à legislação pertinente, de modo que "o art. 60 [da Lei no 9.605/1998] deixa muito claro que, na aplicação de qualquer penalidade, há de se considerar a gravidade do fato e os antecedentes do infrator" (Milaré e Costa Júnior, 2002).

Pertinente notar que não se trata exclusivamente da análise relativa à questão da reincidência, pois o espectro que se pretende abordar é muito mais amplo. Com efeito, trata-se de concepção abrangente, porquanto, "quando se menciona 'os antecedentes do infrator quanto ao cumprimento da legislação de interesse ambiental', pode-se até mesmo considerar fatos na seara cível e administrativa, sejam positivos ou negativos", conforme reconhecido no julgamento da Apelação Cível (AC) 012722- 77.2006.8.26.0189, no dia 15 de março de 2012, relatado pelo desembargador Walter da Silva, integrante do Tribunal de Justiça do Estado de São Paulo (TJSP).

Há, inclusive, repertório jurisprudencial que considerou como antecedentes do infrator o vínculo afetivo estabelecido entre pessoa idônea e ave silvestre não ameaçada de extinção, bem como a ausência de maus tratos ao animal e a dificuldade de sua reintegração ao habitat natural, para confirmar a anulação da respectiva multa ambiental. Nessa toada, confira-se STJ, REsp 1.797.175/SP, relator Ministro Og Fernandes, julgado em 21 de março de.2019; STJ, AgRg no REsp 1.483.969/CE, relator Ministro. Herman Benjamin, julgado em 04 de dezembro de 2014; e STJ, AgRg no REsp 1.457.447/CE, relator Ministro Sérgio Kukina, julgado em 16 de dezembro de 2014.

Semelhantemente às balizas delineadas pela EPA e apesar de divergência doutrinária (Freitas, 2005), já houve pronunciamento dos Tribunais de Apelação brasileiros no sentido de determinar a conversão de penalidade administrativa aplicada por órgão ambiental em sanção menos gravosa ou a redução do valor de multa administrativa, sob os fundamentos de primariedade do infrator, hipossuficiência financeira, mitigação do dano ambiental ou em decorrência da comunicação prévia e voluntária da violação ao agente responsável pela respectiva autuação. 
Nesse sentido, veja-se TJSP, AC 1008830-62.2015.8.26.0405, relator Oswaldo Luiz Palu, julgado em 05 de abril de 2018; TJSP AC 1002466-58.2019.8.26.0462, relator Paulo Ayrosa, julgado em 18 de junho de 2020; Tribunal de Justiça de Santa Catarina, AC 0302405-57.2019.8.24.0023, relator Ronei Danielli, julgado em 25 de agosto de 2020; Tribunal de Justiça do Ceará, AC 0173966-66.2017.8.06.0001, relator Antônio Abelardo Benevides Moraes, julgado em 22 de junho de 2020; Tribunal de Justiça do Distrito Federal e Territórios, AC 0710729-91.2018.8.07.0018, relatora Sandra Reves, julgado em 11 de dezembro de 2019; Tribunal de Justiça do Estado de Rondônia, AC 705014034.2017.8.22.0001, relator Roosevelt Queiroz Costa, julgado em 21 de maio de 2019; Tribunal Regional Federal da 1a Região, AC 0002155-98.2012.4.01.4200, relator Jirair Aram Meguerian, julgado em 18 de fevereiro de 2019; Tribunal Regional Federal da 4⿳亠丷厂 Região, AC 5003565-27.2018.4.04.7106, relatora Maria Isabel Pezzi Klein, julgado em 18 de setembro de 2019; e Tribunal Regional Federal da 5a Região, AC 080146158.2017.4.05.8000, relatora Polyana Falcão Brito, julgado em 21 de agosto de 2018.

Sob esses aspectos, nota-se que, pelos julgados mencionados, diversos fatores podem ser considerados como antecedentes do infrator quanto ao cumprimento da legislação de interesse ambiental, de acordo com a análise casuística. Por isso, irrefutável a assertiva de que a ecoauditoria de conformidade, conduzida nos trilhos da boa-fé, possa servir como elemento a ser apreciada como tal e, assim, capaz de atenuar eventual sanção administrativa.

Outrossim, como argumento de reforço (Freitas, 2005; Milaré, 2015), há que se falar nos princípios da razoabilidade, da proporcionalidade e da igualdade na seara administrativa, com destaque para os arts. 95 e 96, caput, do Decreto no 6.514/2008 (Brasil, 2008).

A Administração Pública, no exercício do seu poder discricionário, deve obedecer a critérios racionalmente aceitáveis, de modo que o raciocínio deve abranger "não apenas soluções rigorosamente lógicas, mas especialmente as que se configuram como razoáveis" (Justen Filho, 2014), obtendo-se da legislação a medida ideal, isto é, aquela que, em cada circunstância, atenda perfeitamente à finalidade da lei e ao crivo da razoabilidade (Mello, 2014).

Enquanto decorrência lógica do quadro ora delineado, a relação entre os meios de que se utiliza a Administração e a finalidade precípua atribuída ao Poder Público deve ser permeada pela proporcionalidade, cuja aferição depende das circunstâncias específicas do caso concreto. Explana-se: embora a normal legal reserve à decisão administrativa um espaço livre, segundo critérios de oportunidade e conveniência, "essa liberdade às vezes se reduz no caso concreto, onde os fatos podem apontar para o administrador a melhor solução" (Di Pietro, 2014).

Estreitamente vinculado à razoabilidade e à proporcionalidade, desponta o dever jurídico da Administração Pública que, ao limitar sua esfera discricionária, impõe que sejam conferidos comportamentos uniformes perante situações iguais (Mello, 2014). A contrario sensu, a igualdade significa tratar desigualmente os desiguais, na medida em que se igualem ou em que se desigualem (Justen Filho, 2014). Para tanto, é preciso que haja uma concreta e efetiva diferença entre duas ou mais situações, bem como seja selecionado um critério apto a avaliar tal diferenciação e compatível com a sua razão de ser.

À luz dos princípios enunciados acima, entre a falta cometida pelo infrator e a sanção imposta pelo Estado deve haver uma relação de ponderação, observando-se a gravidade da lesão, suas consequências, o dolo com que tenha agido o autor e as demais peculiaridades do caso (Freitas, 2005).

Logo, não há como sustentar que ao infrator, de boa-fé e que procedeu à realização de auditoria ambiental de conformidade, seja dispensado idêntico tratamento ao transgressor que não tomou qualquer medida semelhante para, de alguma forma e em qualquer extensão, atenuar os riscos e impactos ambientais derivados de suas atividades

Rev. Bras. Gest. Amb. Sustent., 2021, vol. 8, n. 19, p. 811-829. 
ou operações. A cabo, isso privilegiaria aqueles que intencionalmente blindam sua visão contra o dever constitucional imposto à coletividade de defender o meio ambiente, tal qual estabelecido no art. 225, caput, da Constituição Federal de 1988 (Brasil, 1988), e nada fazem para preservá-lo, conduta totalmente contrária aos ideais da legislação ambiental.

Com efeito, o mecanismo que ora se analisa é vantajoso e proveitoso para todos os envolvidos.

Prima facie, à pessoa, física ou jurídica, concede-se o privilégio de ter a penalidade administrativa que lhe foi imposta atenuada em razão da sua conduta, ainda que transgressora, voltada à preservação do meio ambiente, na medida em que houve a elaboração, de boa-fé, da diligência de conformidade.

Em segundo plano, o órgão ambiental autuante, ao mitigar a sanção administrativa aplicada, incentiva não só o infrator, mas, também, os outros atores que desempenham atividades e empreendimentos potencialmente poluidores e degradadores do meio ambiente a buscar formas alternativas de autopoliciamento quanto à conformidade da sua conduta à legislação ambiental (Prado, 2014), a fim de preservar o ecossistema e, assim, evitar a prática de ato infracional ambientalmente danoso.

Por fim, o ente mais beneficiado por essa articulação é o próprio meio ambiente. Forte no caráter preservacionista, a política de concessão de benefício ora examinada pretende, em última instância, que, mediante a feitura de uma análise de compatibilidade entre o comportamento da unidade auditada e da legislação aplicável, possam ser corrigidas as desconformidades identificadas durante a diligência e das quais se têm conhecimento prévio, mediante ação preventiva, a elidir a ocorrência de um evento lesivo ao meio natural capaz de caracterizar uma infração administrativa ambiental, atenuandose, assim, o risco de eventual responsabilização nessa esfera.

Todavia, promover uma environmental compliance audit não implica necessária e automaticamente a mitigação da responsabilidade administrativa ambiental do infrator, a exigir, no mínimo, que, mediante o exercício do contraditório e da ampla defesa no âmbito do processo administrativo ambiental, disciplinado pelo art. 70, § 4oㅡㄹ da Lei no 9.605/1998 (Brasil, 1998), e pelos arts. 95 e 96, caput, ambos do Decreto no 6.514/2008 (Brasil, 2008), reste comprovado que, por intermédio da diligência empreendida, dos antecedentes do infrator e da sua conduta pretérita, tentou-se, sobretudo, evitar a consumação da infração cometida e, se o caso, do dano ambiental, dentre outros critérios a serem considerados pelas autoridades administrativas.

Caso contrário, entendimento distinto significaria mitigar a sanção administrativa imposta a qualquer ente pelo simples fato de que tenha ele realizado auditoria ambiental de conformidade, independentemente dos reais motivos que a sustentam e da consistência dos seus resultados. Desse modo, perderia a referida diligência sua razão de ser, dado que a elaboração da ecoauditoria serviria de pretexto tão-somente para garantir a impunidade daqueles que não respeitam o ordenamento jurídico, tampouco o meio ambiente.

No atual contexto brasileiro, à míngua de diploma normativo para disciplinar especificamente essa questão, não há outra saída jurídico-administrativa a não ser pela consideração das peculiaridades do caso concreto, para fins de se atenuar eventual sanção em virtude de ter o infrator realizado a devida diligência, sem se por no oblívio os princípios da prevenção, razoabilidade, da proporcionalidade e da igualdade, enquanto limitadores do poder discricionário que de dispõe a Administração Pública.

Contudo, aqui, a crítica há de ser feita:à símile da situação estadunidense, o cenário ideal contemplaria a existência de arcabouço jurídico pátrio específico, seja através de lei, seja por meio de resolução ou instrução normativa do órgão ambiental, para normatizar os critérios exigidos para a concessão da benesse referente à mitigação da responsabilidade administrativa ambiental decorrente da confecção das auditorias ambientais de conformidade, a garantir um núcleo mínimo de previsibilidade e de segurança jurídica às partes envolvidas. 
A problemática posta não significa que se deva importar, total ou parcialmente, a correspondente política originada no estrangeiro, mas dela extrair a essência conceitual e operacional, isto é, o seu método e a sua forma de funcionamento, haja vista o sucesso que lhe é característico.

Imperioso, por outro lado, que sejam traçados parâmetros definidos e pragmáticos, especificando-se a correlação lógica entre o fator discriminante, in casu, representado pelas ecoauditorias de conformidade, sem prejuízo de outros mecanismos de objetivos similares, e a diferença de tratamento conferida àqueles potencialmente abrangidos pelo benefício.

\section{Considerações finais}

Em primeiro plano, merece relevo a auditoria ambiental de conformidade. Esta, enquanto diligência voluntária e conduzida pelas organizações privadas, destinam-se à investigação do grau de cumprimento das atividades desenvolvidas em face da legislação e regulamentação ambientais aplicáveis, mediante $o$ encadeamento das fases de planejamento, de execução e da confecção do relatório, a possibilitar a identificação das situações de não-conformidade e a respectiva correção para adequar-se aos padrões estabelecidos pelo ordenamento jurídico.

Mister, nesse sentido, falar-se no princípio da prevenção, cuja essência repousa sobre o gerenciamento de riscos e impactos conhecidos pela ciência e pressupõe o perigo concreto e certo. Trata-se, com efeito, de fundamento norteador do Direito Ambiental, que decorre da constatação de que as agressões ao meio ambiente, em regra, são de difícil ou impossível reparação, exigindo-se, portanto, que se atue preventivamente para que seja possível evitar a consumação de danos ambientais.

Nessa seara, impõe-se o exame da responsabilidade administrativa em matéria ambiental que, de acordo com a teoria subjetivista que ora se adota, exige, para a caracterização da infração ambiental, não necessariamente materializada pela produção de dano ao meio ambiente, culpa ou dolo na conduta do infrator, além da sua ilicitude e do nexo de causalidade, aplicando-se-lhe, respeitada a ampla defesa e o contraditório no processo administrativo, a correspondente sanção administrativa.

Todavia, à semelhança da política estadunidense promovida pela EPA, comporta o direito pátrio a mitigação da responsabilidade administrativa ambiental em virtude da realização das environmental compliance audits, seja porque, ao impor a penalidade, a autoridade competente deve considerar os antecedentes do infrator no que tange ao cumprimento da legislação de interesse ambiental, seja porque a doutrina e a jurisprudência nacionais imprimem a esta atenuante significação ampla, tendo em vista as circunstâncias específicas do caso concreto e os princípios da razoabilidade, proporcionalidade e igualdade que permeiam o ordenamento jurídico.

Ora, a auditoria ambiental de conformidade, o principio da prevenção e a mitigação da responsabilidade administrativa ambiental representam elementos intrínseca e finalisticamente vinculados, cuja coexistência e correlação reforça a vocação terminativa e comum por eles partilhada: salvaguardar o meio ambiente.

É que a ecoauditoria de conformidade serve como mecanismo para efetivar o princípio da prevenção, porquanto desempenha função investigativa para constatar potenciais desconformidades à legislação que se lhe aplica e para retificá-las, operando-se, sob o prisma temporal, no momento prévio à eventual prática de infração ambiental e de possível consumação de evento danoso ao meio ambiente.

Noutras palavras, patente se denota que a sobredita diligência tenciona tornar cógnitas as disfunções das atividades e dos empreendimentos das organizações privadas, a fim de que elas possam ser gerenciadas, assim como seus riscos e impactos, a evitar atos 
infracionais e danos ambientais, bem como potencial responsabilização administrativa ambiental da pessoa jurídica ou das pessoas físicas que lhe são afetas.

Nesse compasso, a responsabilidade administrativa ambiental, enquanto exercício do poder sancionador estatal e, em especial do poder de polícia ambiental, almeja não só punir os infratores mediante a imposição de penalidades, mas, também, por intermédio do seu caráter intimidativo, profilático e pedagógico, inibir a prática de condutas lesivas ao meio ambiente e conscientizar os atores do corpo social.

Outrossim, mitigar esta variante de responsabilidade em virtude de se ter promovido uma environmental compliance audit não significa premiar aquele que age em desacordo com o ordenamento jurídico. A contrario sensu, implica reconhecer o esforço legítimo e de boa-fé empreendido para se elidir a conduta infracional e, ainda, incentivar especificamente o infrator e, no contexto geral, os outros agentes a esquadrinharem métodos de autopoliciamento, dentre os quais, desponta a auditoria ambiental de conformidade, no que concerne à adequação de suas atividades e operações aos padrões legais e infra legais fixados.

Portanto, sob esses aspectos, é incontroverso que todos os elementos ora abordados convergem à proteção do meio ambiente, visto que, pela interação das suas unidades basilares, há o estímulo à autorregulação das entidades privadas para identificar eventuais situações desconformes à legislação ambiental aplicável e corrigi-las em momento anterior à prática de infração administrativa ambiental, sendo possível, ainda e a depender da análise do caso concreto, atenuar eventual sanção administrativa imposta ao agente que, a despeito da elaboração de auditoria ambiental de conformidade, tenha cometido ato infracional.

Por fim, convém destacar que, no cenário jurídico-brasileiro, seria essencial que o Poder Legislativo ou o próprio órgão ambiental, no desempenho das competências que lhe são outorgadas, assim como se verifica pela perspectiva estadunidense, definisse especificações e critérios objetivos, de acordo com as peculiaridades pátrias, para a concessão da benesse relativa à mitigação da responsabilidade administrativa ambiental decorrente da elaboração de uma ecoauditoria de conformidade, a propiciar segurança jurídica aos envolvidos e a superação da cosmovisão repressivo-punitiva ínsita às autoridades administrativas ambientais.

\section{Conflito de interesses}

O autor declara não haver conflito de interesses.

\section{Referências}

Antunes, P. B. Direito Ambiental. 13. ed. Rio de Janeiro: Lumen Juris, 2011.

Barroso, L. R. Interpretação e aplicação da Constituição. 2. ed. São Paulo: Saraiva, 1998.

Bim, E. F. O mito da responsabilidade objetiva no direito ambiental sancionador: imprescindibilidade da culpa nas infrações ambientais. Revista de Direito Ambiental, v. 57 , p. 42-45, 2010.

Brasil. Decreto no 6.514, de 22 de julho de 2008. Dispõe sobre as infrações e sanções administrativas ao meio ambiente, estabelece o processo administrativo federal para apuração destas infrações, e dá outras providências. Disponível em: <http://www.planalto.gov.br/ccivil_03/_ato2007-2010/2008/decreto/d6514.htm>. Acesso em: 11 abr. 2021. 
Brasil. Lei no 5.172, de 25 de outubro de 1966. Dispõe sobre o Sistema Tributário Nacional e institui normas gerais de direito tributário aplicáveis à União, Estados e Municípios. Disponível em: <http://www.planalto.gov.br/ccivil_03/leis/15172.htm>. Acesso em: Acesso em: 11 abr. 2021.

Brasil. Lei no 6.938, de 31 de agosto de 1981. Dispõe sobre a Política Nacional do Meio Ambiente, seus fins e mecanismos de formulação e aplicação, e dá outras providências. Disponível em: <http://www.planalto.gov.br/ccivil_03/leis/16938.htm>. Acesso em: 11 abr. 2021.

Brasil. Lei no 9.605, de 12 de fevereiro de 1998. Dispõe sobre as sanções penais e administrativas derivadas de condutas e atividades lesivas ao meio ambiente, e dá outras providências. Disponível em: <http://www.planalto.gov.br/ccivil_03/leis/19605.htm>. Acesso em: 11 abr. 2021.

Cabral, A. H. D. C. Direito ambiental: o que é? Revista da Procuradoria Geral do Estado do Rio Grande do Sul, v. 19, n. 47, p. 45-56, 1989.

Campos, L. M. S.; Lerípio, A. Á. Auditoria ambiental: uma ferramenta de gestão. São Paulo: Atlas, 2009.

Canotilho, J. J. G. Direito Constitucional. 7. ed. Coimbra: Livraria Almedina, 2003.

Di Pietro, M. S. Z. Direito Administrativo. 27. ed. São Paulo: Atlas, 2014.

Dino Neto, N.; Bello Filho, N.; Dino, F. Crimes e infrações administrativas ambientais. 3. ed. Belo Horizonte: Del Rey, 2011.

Enterría, E. G.; Fernández, T. R. Curso de Direito Administrativo. São Paulo: RT, 1991.

Espírito Santo. Lei no 4.802, de 2 de agosto de 1993. Dispõe sobre a realização de auditorias periódicas ou ocasionais, a serem efetuadas pelos órgãos governamentais estaduais encarregados da implementação das políticas de proteção ambiental. Disponível em: $\quad$ http://www3.al.es.gov.br/Arquivo/Documents/legislacao/html/LEI48021993. html >. Acesso em: 11 abr. 2021.

Ferreira Filho, M. G. Curso de Direito Constitucional. 38. ed. São Paulo: Saraiva, 2012.

Ferreira, D. Teoria geral da infração administrativa a partir da Constituição Federal de 1988. Belo Horizonte: Fórum, 2009.

Freitas, V. P. Direito Administrativo e meio ambiente. 3. ed. Curitiba: Juruá, 2005.

GAO - United States General Accounting Office. Environmental auditing: A useful tool that can improve environmental performance and reduce costs. Comitee on Governmental Affairs, U.S. Senate, 1995.

Juras, I. A. G. M. Os impactos da indústria no meio ambiente. Brasília: Consultoria Legislativa, 2015.

Justen Filho, M. Curso de Direito Administrativo. 10. ed. São Paulo: RT, 2014.

La Rovere, E. L. (Coord.). Manual de auditoria ambiental. 2. ed. Rio de Janeiro: Qualitymark, 2001.

Lemos, P. F. I. Direito ambiental: responsabilidade civil e proteção ao meio ambiente. 2. ed. São Paulo: RT, 2008.

Machado, P. A. L. Direito ambiental brasileiro. 23. ed. São Paulo: Malheiros, 2015. 
Meirelles, H. L. Direito administrativo brasileiro. 38. ed. São Paulo: Malheiros, 2012.

Mello, C. A. B. Curso de Direito Administrativo. 32. ed. São Paulo: Malheiros, 2014.

Milaré, É. Direito do ambiente. 3. ed. São Paulo: RT, 2015.

Milaré, É; Costa Júnior, P. J. Direito Penal Ambiental: Comentários à Lei no 9.605/98. São Paulo: Millennium, 2002.

Minas Gerais. Lei no 10.627, de 16 de janeiro de 1992. Dispõe sobre a realização de auditorias ambientais e dá outras providências. Disponível em: <http://www.siam.mg.gov.br/sla/download.pdf?idNorma=2243>. Acesso em: $11 \mathrm{abr}$. 2021.

Mukai, T. Direito ambiental sistematizado. 6. ed. Rio de Janeiro: Forense Universitária, 2007.

Nobre Júnior, E. P. Sanções administrativas e princípios de Direito Penal. Revista de Direito Administrativo, v. 219, p. 127-151, 2000.

Oliveira, R. F. Infrações e sanções administrativas. 3. ed. São Paulo: RT, 2012.

Osório, F. M. Direito administrativo sancionador. 4. ed. São Paulo: RT, 2011.

Prado, L. R. Curso de Direito Penal Brasileiro. 13. ed. São Paulo: RT, 2014.

Rio de Janeiro. Lei no 1.898, de 26 de novembro de 1991. Dispõe sobre a realização de auditorias ambientais. Disponível em: <http://alerjln1.alerj.rj.gov.br/CONTLEI.NSF/ c8aa0900025feef6032564ec0060dfff/37d62eca5455abbe03256521007accda>. Acesso em: 11 abr. 2021.

Rio Grande do Sul. Lei no 11.520, de 3 de agosto de 2000. Institui o Código Estadual do Meio Ambiente do Estado do Rio Grande do Sul e dá outras providências. Disponível em: <http://www.al.rs.gov.br/filerepository/repLegis/arquivos/11.520.pdf>. Acesso em: 11 abr. 2021.

Sales, R. Auditoria ambiental e seus aspectos jurídicos. São Paulo: LTr, 2001.

Santos, C. M. C.; Dias, J. E. F.; Aragão, M. A. S. Introdução ao Direito do Ambiente. Lisboa: Universidade Aberta, 1997.

São Paulo. Lei no 9.509, de 20 de março de 1997. Dispõe sobre a Política Estadual do Meio Ambiente, seus fins e mecanismos de formulação e aplicação. Disponível em: <https://www.al.sp.gov.br/repositorio/legislacao/lei/1997/lei-9509-20.03.1997.html>.

Acesso em: 11 abr. 2021.

Schirato, V. R. (Coord.). Estudos atuais sobre ato e processo administrativo. Rio de Janeiro: Lumen Juris, 2017.

Trennepohl, T. Manual de direito ambiental. 8. ed. São Paulo: Saraiva, 2020.

USEPA - United States Environmental Protection Agency. Environmental Auditing Policy Statement. Federal Register, v. 51, n.131, 1986. Disponível em: $<$ https://www.epa.gov/sites/production/files/2014-10/documents/auditingpolicy statement.pdf>. Acesso em: 11 abr. 2021.

USEPA - United States Environmental Protection Agency. Voluntary environmental selfpolicing and self-disclosure interim policy statement. Federal Register, v. 60, n. 63, 1995. Disponível em: <https://www.govinfo.gov/content/pkg/FR-1995-04-03/pdf/958218.pdf >. Acesso em: 11 abr. 2021. 
USEPA - United States Environmental Protection Agency. Incentives for self-policing: Discovery, disclosure, correction and prevention of violations. Federal Register, v. 65, n. 70, 2000. Disponível em: <https://www.epa.gov/compliance/epas-audit-policy>. Acesso em: 11 abr. 2021.

Vitta, H. G. A sanção no Direito Administrativo. São Paulo: Malheiros, 2003.

Witkin, J. B. Environmental aspects of real estate and commercial transactions: From brownfields to green buildings. 3. ed. Chicago: American Bar Association, 2003. 